\title{
815
}

共鳴型消音器を用いたハイブリッドアクティブノイズコントロールに関する研究

\section{The Study on Hybrid Active Noise Contorl Using a Resonator}

\author{
学 上杉考弘（同志社大院） \\ 正 小泉 孝之 (同志社大) \\ 正 辻内 伸好（同志社大）
}

Takahiro UESUGI, Nobutaka TSUJIUCHI, Takayuki KOIZUMI, Doshisha University, Kyotanabe-shi, Kyoto

\begin{abstract}
Many of the noise in ducts, such as air intake noise of vehicles, contain single or multiple large periodic and broadband random noise. Generally, such air intake noise is reduced with multiple resonators that require large-sized area. On the other hand, there are many applications of ANC with Filtered-X LMS algorithm for ductlike structures. However, if the target noise contains very large periodic component, it is difficult to reduce the broadband random noise sufficiently by ANC. In this study, we suggest to apply a new system, namely "hybrid ANC system", in which a Helmholtz resonator is utilized. In the application to the duct noise containing single or multiple periodic components, hybrid ANC can reduce both of the periodic and broadband random noise more effectively than any conventional ANC system.
\end{abstract}

Key Words : Active Noise Control (ANC), Helmholtz Resonator, Hybrid ANC, Periodic Noise

\section{1. 緒言}

管路系騒音の一種であり，自動車の車室内こもり音の一 因となる吸気系䮫音は, 通常複数の共鳴型消音器により対 策がなされるが，その大容量ゆえにエンジンルーム内への 搭載, 通風路の確保などに問題を生ずる。一方, ANC の管 路系騒音への適用が始まっているが，吸気系騒音のように 高音圧レベルの周期成分を含む騒音に適用する場合, 気流 などに伴い発生するランダムな広帯域音は低減されにくい.

本稿では, ダクト系を伝搬する騒音を対象に，周期音， 広帯域音双方でより高い減音効果を得ることのできる消音 システムとして, 共鳴型消音器と Filtered-X LMS アルゴ リズムに基づく ANC を併用したハイブリッド ANC シス テムを構築し，有効性を確認する.

\section{2. ヘルムホルツ共鳴器}

共鳴型消音器の一種であるへルムホルツ型共鳴器の構造 を Fig.1に示す．共鳴周波数に相当する音波が入射すると， 頝部内の空気に気柱振動が生じる。これに接する共鳴室の 空気は圧縮・膨張し，そのため頝部では粘性抵抗により熱 エネルギーに変換され, 吸音が行われる.ここで, ヘルム ホルツ共鳴器の共鳴周波数は次式で与えられる.

$$
f_{r}=\frac{c}{2 \pi} \sqrt{\frac{S_{1}}{S_{2} l_{2}\left(l_{1}+\Delta l\right)}}
$$

ここで c は音速， $S_{1}$ は䅡部管断面積， $S_{1}$ は共鳴室断面積， $l_{1}$ は䅡部管の実長, $l_{1}$ は共鳴室深さ, $\Delta l$ は䅡部管の開口 端補正である，なお，竹繊維により形成される，吸音材の 効果についても検討した。

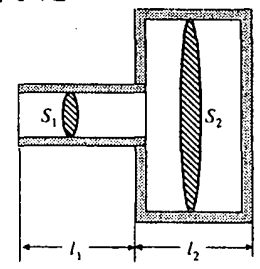

Fig.1 Schematic Diagram of Helmholtz Resonator

\section{3. 共鳴器取付け位固の检討}

\section{1 ダクト系の影䇾を考罢した減音量}

消音器の減音効果指標としては, ダクト出口放射音にお ける音圧レベルの減少量を用いることが望ましく，これを 挿入損失 $(I L)$ と呼ぶ。しかし，IL は共鳴器が取付けられた 系の形状や寸法などによる影響を受けるため, 理論的に算 出することが困難である，そこで間接法 BEM によりダク ト系の影響を考慮した $I L$ の予測を行う.

3.2 間接法 BEM による音晦問題の定式化

一般に圧力 $P$ を従属変数とする波動方程式は， $k$ を波数
として, 次のヘルムホルツ方程式で定式化される ${ }^{1), 2) . ~}$

$$
\nabla^{2} P+k^{2} P=0
$$

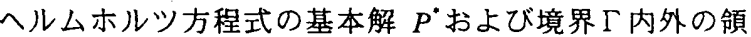
域 $\Omega, \Omega$ 'における解 $P, P$ ', 境界 $\Gamma$ の法線 $n$ を用いるこ とにより, 点 $i$ における音圧 $P_{i}$ について次式を得る.

$$
P_{i}=-\int_{\Gamma}\left(\mu \frac{\partial P^{*}}{\partial n}-P^{*} \sigma_{0}\right) d \Gamma
$$

これが間接法 BEM による表示である。ここで，ルは境界 $\Gamma$ 内外の音圧の差, $\sigma_{0}$ は内部問題と外部問題によって生 じる微分值の差であり，それぞれ次式で定義できる.

$$
\begin{aligned}
& \mu=P-P^{\prime} \\
& \sigma_{0}=\frac{\partial P}{\partial n}-\frac{\partial P^{\prime}}{\partial n}
\end{aligned}
$$

3.3 共鳴器減音量予測のための简略モテル

共鳴器による減音量予測に際して, 先に述べた共鳴器の 減音メカニズムをモデル化することが非常に難しいという 問題点が存在する. そこで, $I L$ 予測のための簡略モデル として, 共鳴器取付け部を挟む上流, 下流側ダクトの接続 面に相当する仮想境界面を設定し、ヘルムホルツ共鳴器へ 入射音圧 $p_{i}$ と透過音圧 $p_{0}$ の比として定義され, 式(5)で与 えられる透過損失 $(T L)$ をこの境界面における る手法を提案する.

$$
T L=10 \log _{10}\left|\frac{p_{i}}{p_{o}}\right|^{2}=10 \log _{10}\left|1+\left(\frac{\left.2 S \sqrt{V S_{1} /\left(l_{1}+\Delta l\right.}\right)}{f / f_{r}-f_{r} / f}\right)^{2}\right|
$$

ただし， $S$ はダクト断面積 $\left[\mathrm{m}^{2}\right], l_{1}+\Delta l$ は䅡部管の実効長 [m], fは周波数 $[\mathrm{Hz}]$ である。

音場解析に用いるダクト系の境界要素メッシュの例を Fig.2 に示す.ここで, Fig.2 中の射影付メッジュが前節で 述べた仮想境界面であり，この定義位置を変えることで共 鳴器取付け位置変化による減音量変化の影響を調べる。な お, 実際の解析は, 汎用音響解析ソフト SYSNOISE Rev 5.3A に上記メッシュモデルをインポートして行った.

\section{4 解析結果}

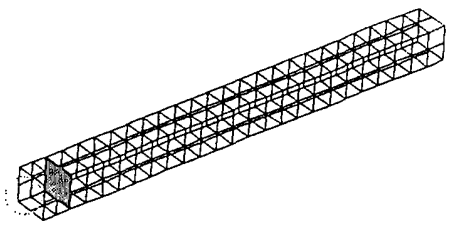

Fig.2 BEM Model of Duct

$120[\mathrm{~Hz}]$ に周期成分を有するモデル騒音を対象音とし， ダクト放射端におけるピーク周波数のIL を求めた結果を Fig. 3 に, 共鳴器取付け前のダクト内における同一周波数 成分の音圧分布を Fig.4に示す. Fig.3より, 解析により求 
めた ILは，その值および共鳴器取付け位置の変更に伴う 変化の傾向について，実測值と良好な一致を示している. また, Fig.4のダクト内音圧分布と比較すると, 减音対象 周波数の音波の音圧レベルが高い点, すなわち音圧分布の 腹にあたる点に共鳴器を設置した場合の IL が大きくなつ ていることが分かる. 以上より，本研究の実験に用いるモ デルダクトに対する共鳴器取付け位固としては, 共鳴周波 数に相当する音波の腹にあたる点が最適と言える.

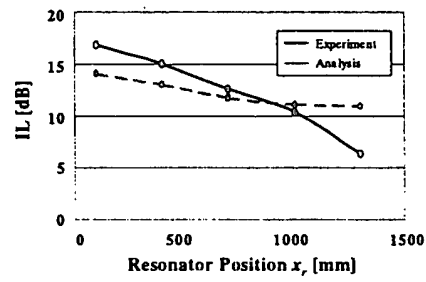

Fig. $3 \mathrm{IL}$ with Helmholtz Resonator $(f r=120 \mathrm{~Hz})$

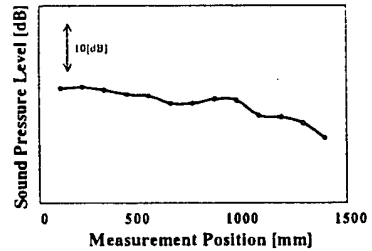

Fig.4 SPL Distribution inside of Duct $(f=120 \mathrm{~Hz})$

$$
\text { 4. ハイブリッド ANC }
$$

実験装置の概略図を Fig.5 に示す. 全長 $1500[\mathrm{~mm}]$ のア クリル製ダクトの一端に騒音発生用のスピーカを設置し, サイン波とホワイトノイズを組み合わせ，管路系を伝搬す る騒音と同様のスペクトルとなるよう作成したモテル騒音 を所定の音圧に增幅して出力し, 制御対象音とした.

$120[\mathrm{~Hz}]$ に高音任レベルの周期成分を有するモデル騒音 にANC を単独で適用した場合のダクト放射端における減 音結果を Fig.6に示す。この場合，オーバーオールで $8.4[\mathrm{~dB}]$ の低減がなされているが，スペクトルを見ると， 大きな減音量が得られているのは周期音近傍の周波数域に 限られていることが分かる。これは，過去の適応制御情報 を蓄積する FIR フィルタを用いた Filtered-X LMS アルゴ リズムが，高音圧レベルの成分を集中的に低減するという 特性によるものであると考えられる.

したがって，ANCによる広帯域騒音の減音効果を向上 させるには, 予め周期音の音圧レベルを低减させることに より，コントローラへの影響を軽減すればよいと考えられ る. そこで，共鳴器の共鳴周波数を周期成分の周波数に一 致させ，予め周期成分を低減させてから ANCによる制御 を行う，以下，この制御をハイブリッドANCと呼ぶ.

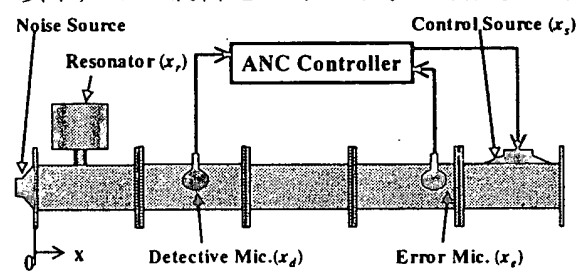

Fig.5 Schematic Diagram of Experimental Setup

$$
\text { 5. ハイブリッド ANCの適用 }
$$

先程と同じモデル騒音にハイブリッド ANC を適用した 場合のダクト放射端における制御結果を前述の Fig.6 に併 記する。この場合，オーバーオールで $12.3[\mathrm{~dB}]$ の低減量を 得ており, ANC 単独の場合に比べて 4[dB]近い向上を示し ている. また，スペクトルを見ると， $120[\mathrm{~Hz}]$ の周期音は ANC 単独の場合 $12.8[\mathrm{~dB}]$ 低減されたのに対し，ハイブリ ッド ANCでは 29.0[dB]低減され，大幅に制御効果を向上
させている，さらに，広帯域騒音も広い周波数帯で顕著な 制御効果を得ていることが分かる.

また，自動車の吸気系に限らず，多くの管路系騒音は， 単独あるいは連結された管路の共鳴により, 複数の周期成 分を有する騒音となることが多い，そこで，周期成分数を 增やした新しいモデル騒音に対する制御効果を確認する.

ANC およびハイブリッド ANCを適用した際の制御効果 を Fig.7 に示す. ダクト放射端におけるオーバーオール低 減量で比較すると, ANC 単独の場合に 11.6[dB]低減され たのに対し，ハイブリッド ANCでは 13.8[dB]とさらに優 れた低減量を実現している．また，スペクトルを見ると， すべての周期成分が十分に低減されており，その上で先程 と同様に広い周波数帯での広帯域騒音に対する制御効果も 向上していることが分かる.

また, 従来複数の共鳴器で対応していたシステムと比べ ると, 単一の共鳴器により周期音および広帯域騒音に対す る高い減音効果を実現し得るハイブリッド ANCは，省ス ペース化の面でも優れた消音システムであると言える.

以上より，本研究で提案したハイブリッド ANC システ 厶は，周期成分を有する管路系騒音の低减に非常に有効な 技術に成り得ると文える.

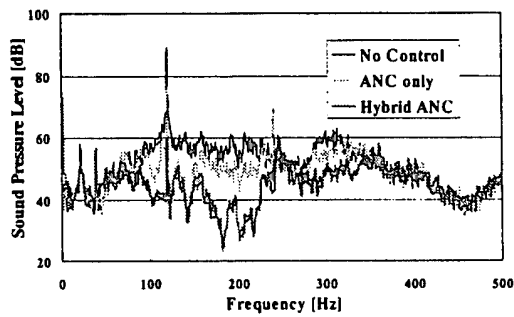

Fig.6 Control Effect by ANC and Hybrid ANC for Noise Containing Single Large Peak

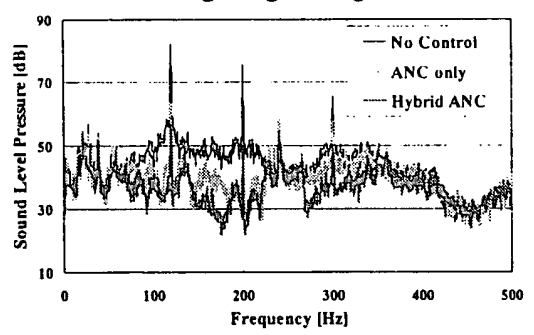

Fig.7 Control Effect with ANC and Hybrid ANC for Noise Containing Multiple Large Peak

\section{6. 結言}

本研究において以下の結論が得られた.

1. システムの各コンポーネントの配置を検討し，ダクト 系を伝搬する周期成分を有する騷音に対して高い減音 効果を持つハイブリッド ANC システムを構築した。

2. 共鳴器で周期成分を予め低減しておくことで, ANC をより広い周波数域でより高い減音量を得られる特性 に変えることができた．

3. ハイブリッドANCは省スペース化にも有効である.

\section{参考文献}

1）C. A. Brebbia, S. Walker 共著,「境界要素法の基 礎と応用」，(1981），21-44.

2）上原洋志, 大久保稔, 荻田広, 「SYSNOISE Users Meeting in JAPAN 2000」, (2000), 79-84.

謝辞

本研究の一部は, 文部省高度化推進特別経費 (平成 11 年度新技術開発研究) および同志社大学 RCAST による支 援を受けた。記して謝意を表す。 